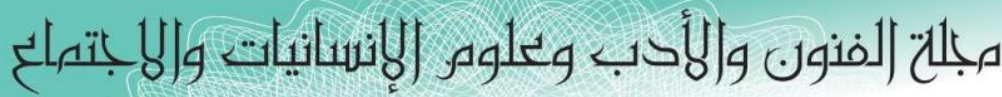

Journal of Arts, Literature, Humanities and Social Sciences

ISSN online: 2414 - 3383

ISSN print: 2616 - 3810

العدد (39) حزيران - يونيو 2019

\title{
Analytical Study on Organizational Ethnicity and it's Induce towards Workplace Assortment and Enclosure
}

\author{
Ramyar Rzgar Ahmed \\ Dean of College of Administration and Economics \\ Lebanese French University \\ Erbil, Kurdistan, Iraq \\ ramyaracc@lfu.edu.krd
}

\author{
Rabiyathul Basariya \\ College of Administration and Economics \\ Lebanese French University \\ Erbil, Kurdistan, Iraq
}

\begin{abstract}
Change is the only constant. Evolution and transformation is the natural outcome of change and adapting is crucial for survival. This law of nature is true for organization too. Understanding the capabilities of a diverse talent pool that is more connected than ever and providing an inclusive environment for talent to thrive and contribute is gradually becoming a non-negotiable aspect to be blended into the culture of a place, be it an organization or a nation. Thus the culture, in the context of this paper, the organization culture, becomes one of the key drivers of Diversity and Inclusion. This paper is an attempt to understand the key factors of organizational culture that impacts the diversity and inclusion matters in a workplace, with specific reference to Information Technology organization in India, specifically in Chennai.
\end{abstract}




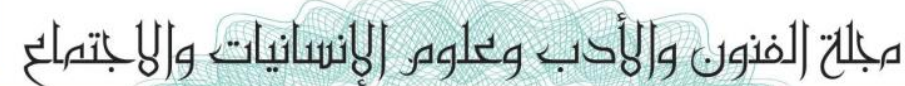

العدد (39) حزيران - يونيو 2019

\section{INTRODUCTION:}

One of the earliest articulations of the anthropological meaning of the term "culture" came from Sir Edward Taylor in 1871 is that "Culture, or civilization, taken in its broad, ethnographic sense, is that complex whole which includes knowledge, belief, art, morals, law, custom, and any other capabilities and habits acquired by man as a member of society" ${ }^{1}$. The knowledge, customs, beliefs gets passed on to every new comer into the group and the norms get confirmed more strongly with every new person inducted. The new comer gets acclimatized or acculturated to 'the ways the things are done around here' (Deal and Kennedy,1982). In an organisational context it gets even more interesting as diverse set of people come together and get oriented to the culture of a given workplace. Quite often culture gets defined at the top, percolates through the hierarchy and begins to take shape as a strong element that influences everything happening in and around the organisation. It is an invisible yet powerful factor that Prof. Sumantra Ghoshal of London Business School so beautifully defines as the smell of the place.

Increasingly organisations realize the value in building a strong positive culture as culture tends to impact every process and eventually the business outcomes. Culture plays a big role in an organisation's ability to attract, nurture, retain and grow talent. Multiple research proves the impact of culture on leadership approach, ability to innovate, team efficiency, inclusion strategies and employee engagement. While few of these aspects are researched, that are many other areas that gets impacted in different ways. Hence it becomes important to measure and manage this elusive element of culture. Successful organizations seem to have developed the ability to measure the cultural factors that enables or disables them such that they can accentuate the strengths and come up with fixes for areas of weakness. 


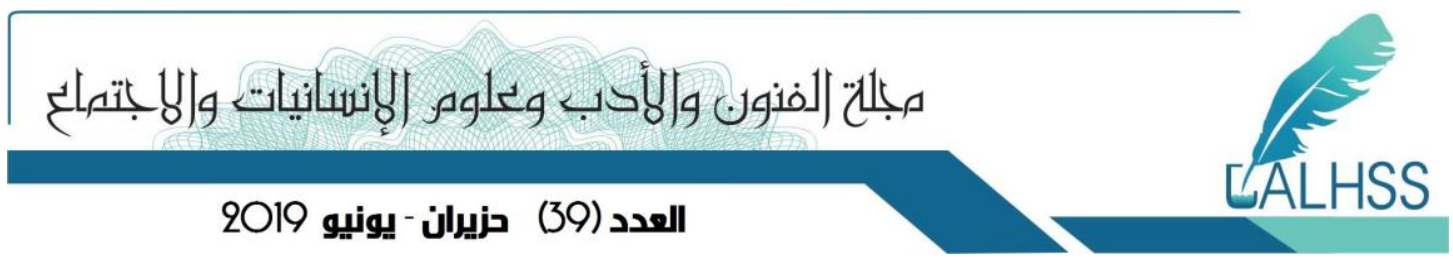

Culture assessments are a complex phenomenon as there is no one definition of what constitutes culture. Edgar defines culture "as a pattern of shared basic assumptions that was learned by a group as it solved its problems of external adaptation and internal integration, that has worked well enough to be considered valid and, therefore, to be taught to new members as the correct way to perceive, think, and feel in relation to those problems:"2 Edgar observers that culture and leadership are highly intertwined. He further states that it is the responsibility of the leaders to form and manage the culture bringing out the important element of leadership.

\section{Objectives of the study}

The main objectives of this study are as follows

- To explore the organisational cultural at workplace

- To examine workplace diversity \& inclusion

- To analyse the impact of organisational culture on diversity and inclusion

Measuring the Organisational culture and Diversity \& Inclusion

Organizational culture is a complex indicator to measure. There are many value based and behavioural indicators based instruments developed over the years. The value based instruments assess the shared values and norms whereas the behavioural indicator based instruments focus on the exhibited behaviour of the people in a group to map the culture. One of the leading value based assessment framework is Organizational culture profile (OCPChatman \& Jehn, 1991, O’ Reilly at al. 1991) ${ }^{3}$. In this framework culture is represented by seven distinct values of Innovation, Aggressiveness, Outcome orientation, Stability, People orientation, Team orientation and Details orientation.

While diversity is one side of the coin, the inclusion is the other. The organisational culture plays a vital role in influencing the diversity and inclusion matters in any workplace as the inclusive behaviours are manifestation of the how well the values are imbibed by the 


\section{مبلح" الفنون والأكب وعلوه الإنسانيات و|لإبتماتع}

\section{العدد (39) ريران - يونيو 2019}

members of a group. Thus the culture assessment tool Organizational Culture Survey (OCS), that includes key inclusion matters in employee life cycle was chosen for this study. The OCS was created by Glaser, Zamanou, \& Hacker (1987) as a quantitative method for measuring organizational culture. The survey contains 31 statements that are rated on 5 point Likert scale and focuses on 6 broad areas of teamwork, morale, supervision, involvement, information flow and meetings. While these are not exhaustive indicators of organisational culture measurement, they encompass some of the core workplace touch points that enables the employee to experience the values and how they are translated into practices.

A sample population of 229 members of IT industry responded to the survey questionnaire that includes the statements from OCS and a question pertaining their perception on diversity and inclusion aspects in their organisation. The survey outcome has been examined using multiple regression analysis to find if the organisational culture factors have an impact diversity and inclusion matter and if so, which factors has most influence.

Impact of Organizational culture on Diversity \& Inclusion

The organizational cultural factors such as team work, morale, information flow, involvement, supervision and meetings are used as inputs in regression analysis to identify predictors of diversity inclusion. The method used to predict diversity inclusion is multiple regression analysis. In this study, Diversity \& inclusion (Y) is dependent variable; Team work (X1), Morale (X2), Information flow (X3), Involvement (X4), Supervision (X5) and Meetings (X6) are predictor variables.

The table shows that the combination of six factors together contributed to $91.7 \%$ effect on Diversity \& Inclusion. The $\mathrm{R}^{2}(0.841)$ for the overall study on the above six factors suggests that there is a strong effect of these independent variables on Diversity inclusion. However, based on the adjusted $\mathrm{R}$ square value of 0.816 , these elements contribute $81.6 \%$ to dependent variable. 


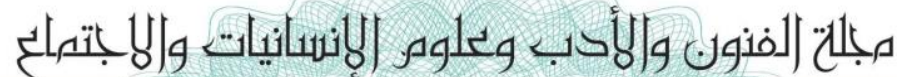

العدد (39) حزيران - يونيو 2019

Table 1

Multiple regression model for Diversity \& Inclusion based on Organizational culture

\begin{tabular}{|c|c|c|c|c|c|c|c|}
\hline $\begin{array}{c}\text { Independent } \\
\text { variables }\end{array}$ & $\begin{array}{r}\text { Unstal } \\
\text { Coe }\end{array}$ & $\begin{array}{l}\text { ardized } \\
\text { cients }\end{array}$ & $\begin{array}{c}\text { Standardiz } \\
\text { ed }\end{array}$ & & & \multicolumn{2}{|c|}{$\begin{array}{c}\text { Statistical } \\
\text { inference }\end{array}$} \\
\hline & B & $\begin{array}{l}\text { Std. } \\
\text { Error }\end{array}$ & Beta & $\mathbf{t}$ & Sig & & F value \\
\hline Constant & 27.792 & 11.495 & & 2.418 & .021 & & \\
\hline X1-Team work & .721 & .567 & .138 & 1.272 & .211 & & \\
\hline X2-Morale & 1.419 & .703 & .271 & 2.020 & $\begin{array}{c}.049 * \\
*\end{array}$ & $\begin{array}{l}\mathrm{R}= \\
0.917\end{array}$ & \\
\hline X3- Info flow & -.063 & & -.006 & -.044 & .965 & $\mathrm{R}^{2}=$ & $33596 * *$ \\
\hline $\begin{array}{l}\text { X4- } \\
\text { Involvement }\end{array}$ & 2.579 & 1.222 & .249 & 2.111 & $\begin{array}{c}.041 * \\
*\end{array}$ & $\begin{array}{l}0.841 \\
\text { Adjust }\end{array}$ & \\
\hline $\begin{array}{l}\text { X5- } \\
\text { Supervision }\end{array}$ & .152 & .725 & .031 & .209 & .835 & $\begin{array}{r}\text { ed } R^{2}= \\
0.816\end{array}$ & \\
\hline X6- Meeting & 2.926 & .989 & .362 & 2.959 & $\begin{array}{c}.005^{*} \\
* *\end{array}$ & & \\
\hline
\end{tabular}

**Significant at 5\% level $\quad * * *$ Significant at $1 \%$ level

The F value (33.596) is significant which implies that the model is fit. From the table it is found that Morale, Involvement and Meetings give significant impact to Diversity inclusion. It is clear that independent variable with higher level of $\beta$ has higher impact on dependent variable. In this study result reveal that the variable X6 $(\beta=0.362, \mathrm{p}<0.01)$ is the most influential factor, $X 2(\beta=0.271, p<0.05)$ is ranked second, followed by $X 4(\beta=0.249$, $\mathrm{p}<0.05)$ also show a significant contribution. 


\section{العدد (39) حزيران - يونيو 2019}

The standardized coefficients Beta column, gives the coefficients of independent variables in the regression equation.

$$
Y=0.138 X_{1}+0.271 X_{2}-0.006 X_{3}+0.249 X_{4}+0.031 X_{5}+0.362 X_{6}
$$

\section{Findings and Discussion:}

The finding of meeting as the most influencing factor resonates well with the IT industry that works largely with virtual and distributed teams with meeting being the key occasion when the culture of the place or the element of inclusion is experienced by the members. However, most managers believe that the time spent on meeting can be an unproductive but meetings are the inevitable part of a workday especially in knowledge industry. One of the interesting findings of a study on $3 \mathrm{M}$ on meeting effectiveness showed that only $19 \%$ of the survey participants felt that they were able to influence the outcome of the meeting while the remaining believed that they somewhat influenced or had no influence at all $^{4}$. This belief could be an outcome of feeling of being included in the process. If members do not feel included then they may become reluctant to contribute by limiting information, thought and knowledge sharing which may defeat the core purpose of the meetings.

In a study conducted on the employees of multiple organisation associated with Industrial relation centre, US found five key factor of morale which included organization \& management, material rewards, immediate supervision, fellow employees and job satisfaction ${ }^{5}$. Interestingly the factor of 'immediate supervision' had a high correlation with the rest of the factors emphasizing the importance of the role a manager plays in improving the morale of the team and its members. It is logical that an employee who feels valued is more engaged in the work and tends to experience a high morale. A study on exploring the relationship between morale and workplace productivity in a sample population in Australian

workplace found that morale influenced productivity in a liner way ${ }^{6}$. In other words, morale 


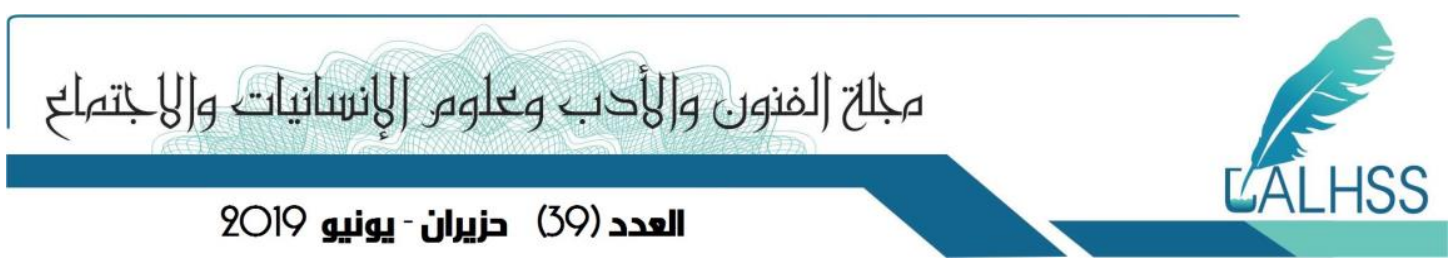

impacted work efforts leading to higher productivity amongst employees experiencing higher morale.

This logically flows to the next significant factor of involvement. An employee who believes in being asked for not just suggestions on how to improve that work but also has a say on the decisions that affects one's work and is valued for the suggestions provided, feels involved in the job. Basis a survey conducted with 239 employee of an IT organisation, the authors argue that employee involvement constitutes three essential variables such as participation in decision making, teamwork and communications ${ }^{7}$. Further the study identified three dimension of employee effective attitudes (job satisfaction, commitment, and stress), and three dimensions of organizational climate (bureaucracy, innovation, and support) of which supportive climates and commitment significantly predicted each of the employee involvement variables. The study shows how team work plays an integral role in improving the employee involvement.

A seamless flow of Information in workplace is vital for effective performance of its members and higher productivity. Keeping the information flowing in both directions is key to creating a transparent and trust based workplace that people prefer to be part of. A research on organisational market information processes finds that information processes are fundamentally people processes that involve commitment and trust amongst the members ${ }^{8}$. The same study further suggests that information utilization process is a strong predictor of an organisation's ability to build new products, focus on timeliness and being creative, all of these could be competitive advantages in a fast pace world that craves for differentiators to survive.

\section{CONCLUSION:}

Organisations need to create a culture where every employee feels included. This begins with one of the key work related interactions such as the meetings where the employee should be feeling free to participate, share views and feel valued for the contributions. From approaching the entire process with a clear outcome based mind set to ensuring that the decisions made during the meetings are implemented to converting it into a platform where 


\section{مبلح" الفنون والأكب وعلوه الإنسانيات و|لإبتهاتع}

\section{العدد (39) ريران - يونيو 2019}

innovative ideas a freely brought up for discussion, the managers carry a big responsibility of enabling inclusion. In an IT work environment meetings form a significant part of the day's interaction as quite often different teams build different parts of a solution which is packaged and delivered as the final outcome to clients. Meeting are mainly used for collaborating, updating and reviewing. Managing the efficiency of this factor is crucial for timely delivery and avoids redundancy or rework. Thus it seems logical for this factor to be having the most significant impact on the inclusion matters in the IT work environment.

The factors of morale and involvement could be tagged as internal factors, crucial for employee engagement and talent retention. In a knowledge based industry that is always facing a war of talent, retaining talent, building an engaged and committed workforce can be a game changer. Further in IT work environment, employees work on short and long term projects. Even the employees working on long term projects are rotated to different other projects after a stipulated period to facilitate knowledge enhancement, cross pollination of ideas and for balancing the project cost. This kind of working does have an impact on the ways an employee relates to important factors of team working, supervision and information flow.

When employees come together as a team to address a deliverable for a short period of time, the meeting becomes the platforms where they relate to each other, position what they are capable of bringing to the table, showcase their value adds and seek the recognition for their contribution. Thus the three factors of meetings, morale and involvement are showing a higher impact and the factors of team working, supervision and information flow are subsequent factors influencing the organisational culture seems to fit well in the context of IT work environment. Applying this study to employees in different locations or different industries may help in prioritizing the influencing factors and empower the workplaces to build stronger mitigating strategies to enable inclusion. 


\section{REFERENCES}

1. Tylor, Edward. 1920 [1871]. Primitive Culture. Vol 1. New York: J.P. Putnam's Sons.

2. Edgar Schien, Organisational culture and Leadership, Third edition, Published by Jossey-Bass A Wiley Imprint 2004

3. Source: https://open.lib.umn.edu/principlesmanagement/chapter/8-4-measuringorganizational-culture/

4. Petet M. monge, Charles McSween, JoAnne Wyer, A profile of Meetings in corporate America: Result of the 3M meeting effectiveness study, 1989, CEO Publication, G 90-8 (170)

5. Melany E. Baehr and Richard Renck, The Definition and Measurement of Employee Morale, Administrative Science Quarterly, Vol. 3, No. 2 (Sep., 1958), pp. 157-184, Published by: Sage Publications, Inc. on behalf of the Johnson Graduate School of Management, Cornell University

6. David L. Weakliem, Stephen J. Frenkel, Morale and Workplace Performance, Work and Occupations, Vol 33, Issue 3, pp. 335 - 361, Aug 2016

7. Mark A. Shadur, Rene Kienzle (Queensland University of Technology), John J. Rodwell (Deakin University), The Relationship between Organizational Climate and Employee Perceptions of Involvement, The Importance of Support. Volume: 24 issue: 4, page(s): 479-503, Issue published: December 1, 1999, DOI: https://doi.org/10.1177/1059601199244005 